\title{
An Upper Triassic, Norian-Rhaetian, outlier in Skåne, southern Sweden
}

\author{
MIKAEL ERLSTRÖM \& DOROTHY GUY-OHLSON
}

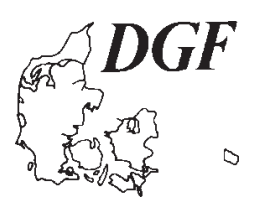

\begin{abstract}
Erlström, M. \& Guy-Ohlson, D.: An Upper Triassic, Norian-Rhaetian, outlier in Skåne, southern Sweden. Bulletin of the Geological Society of Denmark, Vol. 45, pp. 89-97. Copenhagen 1999-01-30. https://doi.org/10.37570/bgsd-1998-45-09

A new outlier of Upper Triassic sedimentary strata has been found in a small fault bounded trough within geological domains dominated by Precambrian crystalline rocks. It was discovered in connection with pre-investigations and excavation of a new railway tunnel through the Hallandsås Horst in the north-western part of Skåne. It consists of a $15 \mathrm{~m}$ thick succession of pre-Quaternary strata on top of the kaolinized crystalline basement. The lower $10 \mathrm{~m}$ consists of red clays, mudstones and sandstones, interpreted as belonging to the Norian Kågeröd Formation. It is followed by fine and medium-grained, light grey and whitish, crossbedded sandstones, clays, coals and rootlet beds belonging to the RhaetianHettangian Höganäs Formation. Palynological investigations reveal a rich well preserved palynomorph assemblage of Rhaetian age for the upper part of the section which is interpreted to have been deposited in a brackish-freshwater environment. The new locality together with other scattered outliers north-east of the Kullen-Ringsjön-Andrarum Fault Zone, represent the erosional remains of a preexisting, much larger distribution of Upper Triassic strata in Skåne.
\end{abstract}

Keywords: Upper Triassic, Kågeröd Formation, Höganäs Formation, distribution, lithology, palynology, deposition, Skåne, southern Sweden.

M. Erlström [mikael.erlstrom@sgu.se], Geological Survey of Sweden, Kiliansgatan 10, SE-223 50 Lund, Sweden. D. Guy-Ohlson [rare-pp@algonet.se], Swedish Museum of Natural History, Box 50007, SE-104 05 Stockholm, Sweden. 14 May 1998.

Skåne is located within a structurally complex zone on the SW margin of the Baltic Shield (Fig. 1). The structural framework is dominated by WNW-NW oriented lineaments and fault systems along which repeated movements have occurred during Mesozoic times (Norling \& Bergström 1987; Erlström, Thomas, Deeks \& Sivhed 1997; Michelsen 1997). Skåne constituted during the Mesozoic a marginal depositional area to the Danish Basin. The deposition was consequently, especially during the Triassic and Jurassic, strongly influenced by even minor sea-level changes. The Triassic-Jurassic sedimentation in Skåne was also influenced by block faulting which in combination with sea level changes led to significant variation in thickness and stratigraphic representation of the Triassic-Jurassic between blocks (Norling \& Bergström 1987; Bergström 1985). Lower, Middle and lower Upper Triassic deposits are only preserved in the SW parts of Skåne (Sivhed \& Erlström 1998a-d).
In other parts of Skåne, the Early and Middle Triassic were apparently periods of non-deposition, although this may be the result from erosion during or after Late Cretaceous inversion and Neogene regional uplift events (Boldreel \& Japsen 1998). It was not until Late Triassic times that there was a wider geographic distribution of strata. For the main part of Skane the Mesozoic sedimentary record commenced with the deposition of Upper Triassic sediments either directly on top of the crystalline basement or on top of Lower Palaeozoic shales, thus, representing a significant hiatus from the Late Silurian to the latest Triassic. The overall transgressive nature of the Rhaetian-Sinemurian resulted in a progressively changing depositional environment, from floodplain to shallow marine. By the Early Sinemurian all of Skåne was probably covered by shallow marine environments (Norling, Ahlberg, Erlström, \& Sivhed 1993; Jubitz, Znosko, \& Franke 1988). At the present day Upper Triassic-Lower 


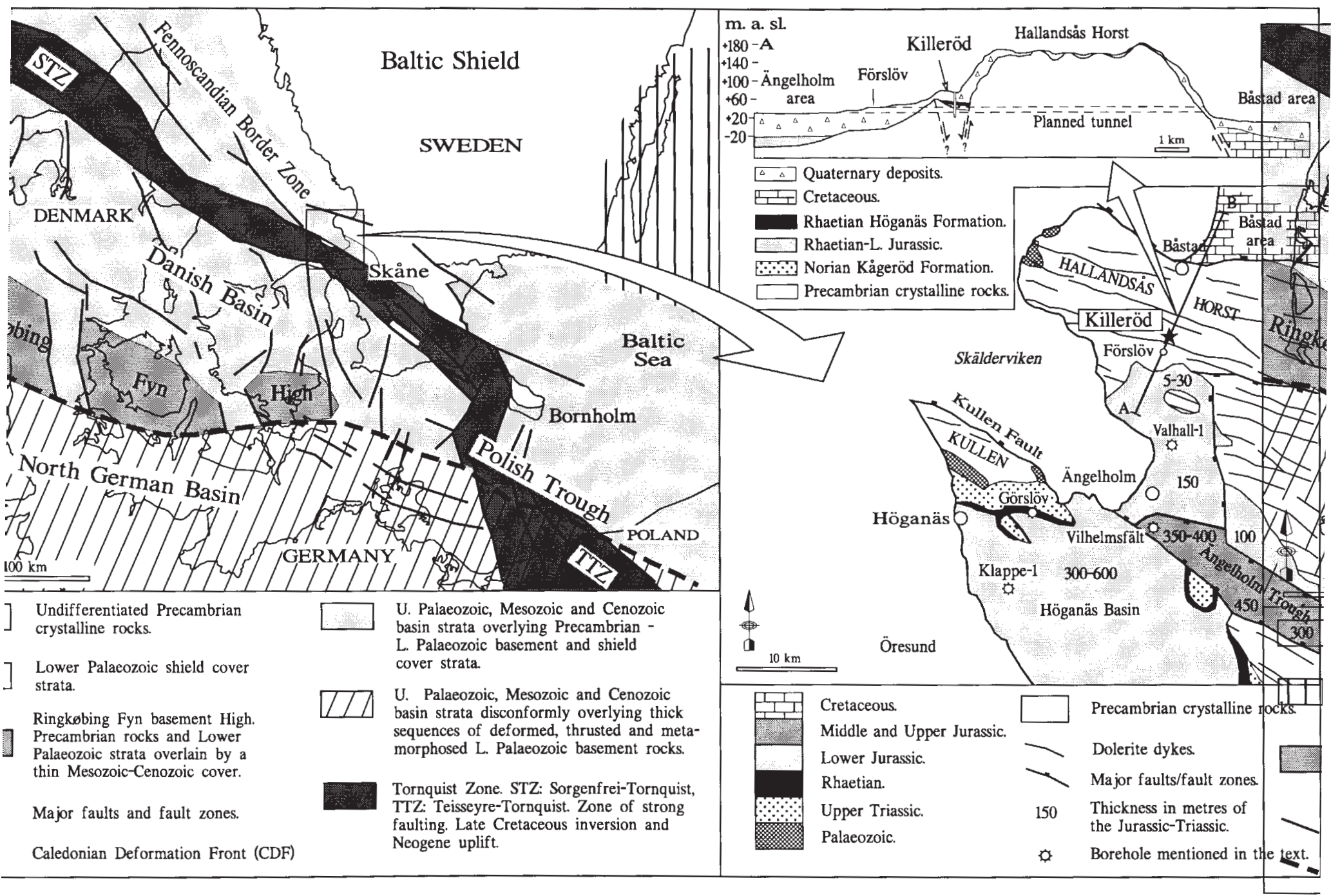

Fig. 1. A schematic map showing the main geological framework of Skåne and adjacent areas. The map to the right presents the general bedrock geology of NW Skåne and the location of the finds at Killeröd. 
Fig. 2. Lithological and sedimentological log of the outlier at Killeröd.

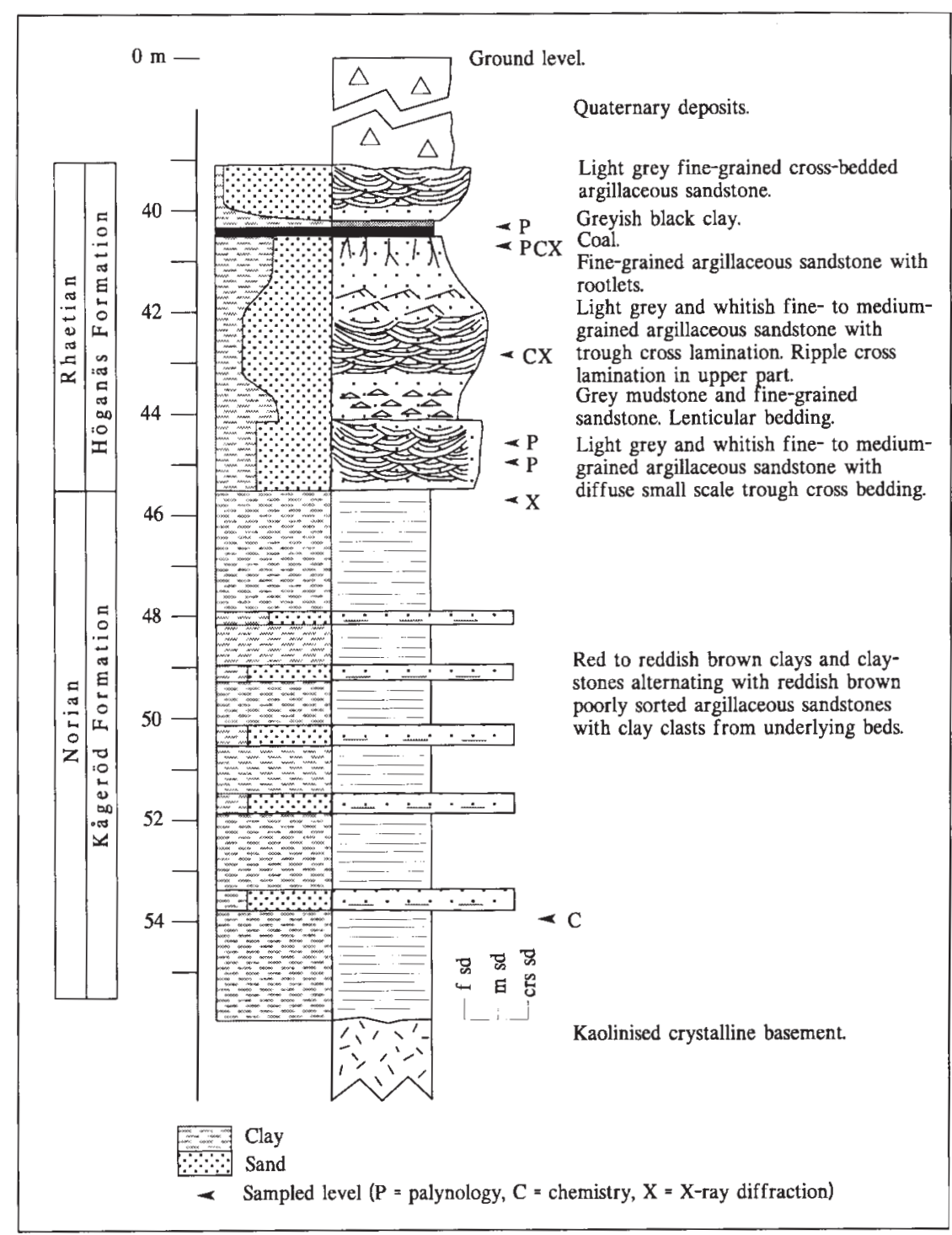

Jurassic strata in Skåne represent remnants of this previous much wider distribution. Mesozoic block tectonics and inversion of the Sorgenfrei-Tornquist Zone have resulted in erosion and extensive removal of preexisting strata, especially to the north-east of the Kullen-Ringsjön-Andrarum Fault Zone.

Knowledge about the Late Triassic-Early Jurassic sedimentation within these geological domains dominated by Precambrian crystalline rocks is therefore largely based on scattered outliers. The location of these outliers adds valuable information concerning stratigraphy, deposition, palaeogeography and palaeotectonic evolution of this marginal part of the Danish Basin. The new outlier at Killeröd increases this knowledge. The aim of this paper is to give a comprehensive report about the new outlier, focusing on its stratigraphy and lithology, and to discuss its significance and implication in the light of previous knowledge of the Upper Triassic-Lower Jurassic in Skåne.

\section{Locality and methods}

The new outlier is located at Killeröd, $5 \mathrm{~km}$ north of Förslöv in NW Skåne, on the southern slope of the Hallandsås Horst north of Ängelholm (Fig. 1). In 1988, cuttings from water well drillings indicated the presence of a pre-Quaternary succession of coal, clay, sand and red clay on top of the crystalline basement. The stratigraphical affinity of these initial findings could, however, not be ascertained. The finds were verified 
in 1995 during core drilling and geophysical investigations carried out in front of the planned tunnel entrance on the southern side of the Hallandsås Horst. Geophysical investigations, including resistivity, VLF and reflection seismic methods, revealed a $<60$ m deep depression filled with an upper approximately 40 meters thick unit of Quaternary deposits and a lower unit with geophysically differently characterised rock types on top of the crystalline basement (Dahlin 1996).

The data presented in this paper comes from description and sampling of two closely spaced $70 \mathrm{~m}$ deep cored boreholes, information from water wells (SGU well archive) and from percussion boreholes made in connection with the Hallandsås tunnelling project. The cores were described lithologically in the field. One of them was sampled for palynological, XRD and chemical analyses (Fig. 2). Only minor core losses occurred in the sampled pre-Quaternary section between 39.2-55.9 m.

Multicomponent ICP-AES chemical analyses were carried out on bulk samples from three levels, one at 40.7 m consisting of a dark grey argillaceous very finegrained sandstone directly below a coal bed, one at $42.8 \mathrm{~m}$ (grey argillaceous fine sand) and one at 53.9 $\mathrm{m}$ (red clay). X-ray diffraction was done on both the bulk and the clay fractions of three levels, at $40.7 \mathrm{~m}$, $42.8 \mathrm{~m}$ and $45.5 \mathrm{~m}$ (red clay). Samples for palynological investigations were taken at $40.3 \mathrm{~m}$ (coal bed), $40.7 \mathrm{~m}, 44.5 \mathrm{~m}$ and $44.9 \mathrm{~m}$ (argillaceous fine sand). Sampled levels are marked in Figure 2.

\section{Results}

\section{Sedimentology and petrography}

The cores verify a $15 \mathrm{~m}$ thick succession of stratified sedimentary rocks below $39.2 \mathrm{~m}$ of Quaternary deposits. The top of the crystalline basement lies $55.9 \mathrm{~m}$ below the ground level and consists of heavily weathered gneisses and amphibolites. The pre-Quaternary sediments on top of the basement consist of approximately $10 \mathrm{~m}$ of red to reddish brown sandy clays and mudstones, overlain by a $5 \mathrm{~m}$ thick greyish to white, fine-grained sand-dominated unit with coal, clay and rootlet horizons (Fig. 2).

The lower reddish brown unit between 45.5 to 55.9 $m$ depth consists of alternating beds of reddish brown clays, mudstones and poorly sorted medium- and coarse-grained sandstones. The basal bed boundaries of the sandstones are erosive, indicated by clay clasts from the underlying clay in their basal parts. Other sedimentary structures were not found. The clays and mudstones are dominated by kaolinite and a minor amount of mixed-layer clay minerals (smectite-illite). The clay beds also contain a significant amount of arenaceous material (quartz and feldspars). The XRD analysis reveals a significant amount of hematite in the clays. The chemical analysis of the red clay at 53.9 $\mathrm{m}$ resulted in the following contents; $\mathrm{SiO}_{2}: 50.1 \%$, $\mathrm{Al}_{2} \mathrm{O}_{3}: 23.1 \%, \mathrm{Fe}_{2} \mathrm{O}_{3}: 13.8 \%, \mathrm{CaO}: 0.87 \%, \mathrm{Na}_{2} \mathrm{O}$ : $0.01 \%, \mathrm{~K}_{2} \mathrm{O}: 0.7 \%, \mathrm{TiO}_{2}: 1.3 \%, \mathrm{MnO}: 0,03 \%, \mathrm{MgO}$ : $0.2 \%$ and $\mathrm{P}_{2} \mathrm{O}_{5}: 0.4 \%$.

The strata above $45.5 \mathrm{~m}$ displays sediments with quite different characteristics (Fig. 2). The beds between 44.1 and $45.5 \mathrm{~m}$ are composed of a light grey and whitish fine- and medium-grained sandstones with diffuse trough cross-lamination followed by a grey argillaceous fine-grained sandstone topped by a dark grey mudstone with lenticular bedding (44.1-43.4 m). These beds are overlain by whitish medium-grained sandstones with trough cross lamination (43.4-42.2 $\mathrm{m})$ and fine-grained sandstones with ripple lamination (42.2-41.6 m) topped by an argillaceous sandstone with rootlets. The rootlets begin from the base of a thin coal layer between 40.5 and $40.2 \mathrm{~m}$ and penetrate $10-40 \mathrm{~cm}$ into the underlying sandstone. A 10 $\mathrm{cm}$ thick greyish black clay occurs above the coal overlain by cross-bedded fine- and medium-grained argillaceous sandstones between $40.1 \mathrm{~m}$ and to the top of the pre-Quaternary sequence at $39.2 \mathrm{~m}$.

The clay mineral suite at 40.7 and $42.8 \mathrm{~m}$ is dominated by well crystallised kaolinite and mica. Small amounts of slightly swelling mixed layer (smectiteillite) components were also found. The XRD analysis also revealed significant amounts of rutile and zirkon minerals in the bulk fraction of the sands. The chemical analyses of the argillaceous fine sands resulted in the following ranges of the main components; $\mathrm{SiO}_{2}:$ 65-70 \%, $\mathrm{Al}_{2} \mathrm{O}_{3}: 14-18 \%, \mathrm{Fe}_{2} \mathrm{O}_{3}: 2-3 \%, \mathrm{CaO}:$ $0.15-0.2 \%, \mathrm{Na}_{2} \mathrm{O}: 0.14-0.19 \%, \mathrm{~K}_{2} \mathrm{O}: 1.7-2.9 \%, \mathrm{TiO}_{2}$ : $3.1-4.5 \%$, MnO: $0.05-0.1 \%, \mathrm{MgO}: 0.17-0.18 \%$ and $\mathrm{P}_{2} \mathrm{O}_{5}: 0.07-0.08 \%$.

\section{Palynology}

From the Killeröd locality four core samples, from $40.3,40.7,44.5$ and $44.9 \mathrm{~m}$ depth, were prepared chemically using standard techniques for the extraction of organic-walled microfossils. The resulting organic residues were examined using transmitted light and scanning electron microscopy for the presence of palynomorphs (Fig. 3). The upper two samples (40.3 and $40.7 \mathrm{~m}$ ) contained numerous (literally thousands) of well preserved palynomorphs, whereas the latter two samples were almost barren with no stratigraphically diagnostic microfossils. Sample $40.3 \mathrm{~m}$ is characterised by the presence of the following important diagnostic species: Ricciisporites tuberculatus Lundblad, Quadraeculina anellaeformis Maljavkina, Pinuspollenites minimus (Couper) Kemp and Monosulcites minimus Couper with Vitreisporites pallidus (Reissinger) Nilsson, Marattisporites scabratus Couper and Conbaculatisporites mesozoicus Klaus as important accessory species.

The sample at $40.7 \mathrm{~m}$ is richer than the previous in all of the diagnostic and important accessory paly- 

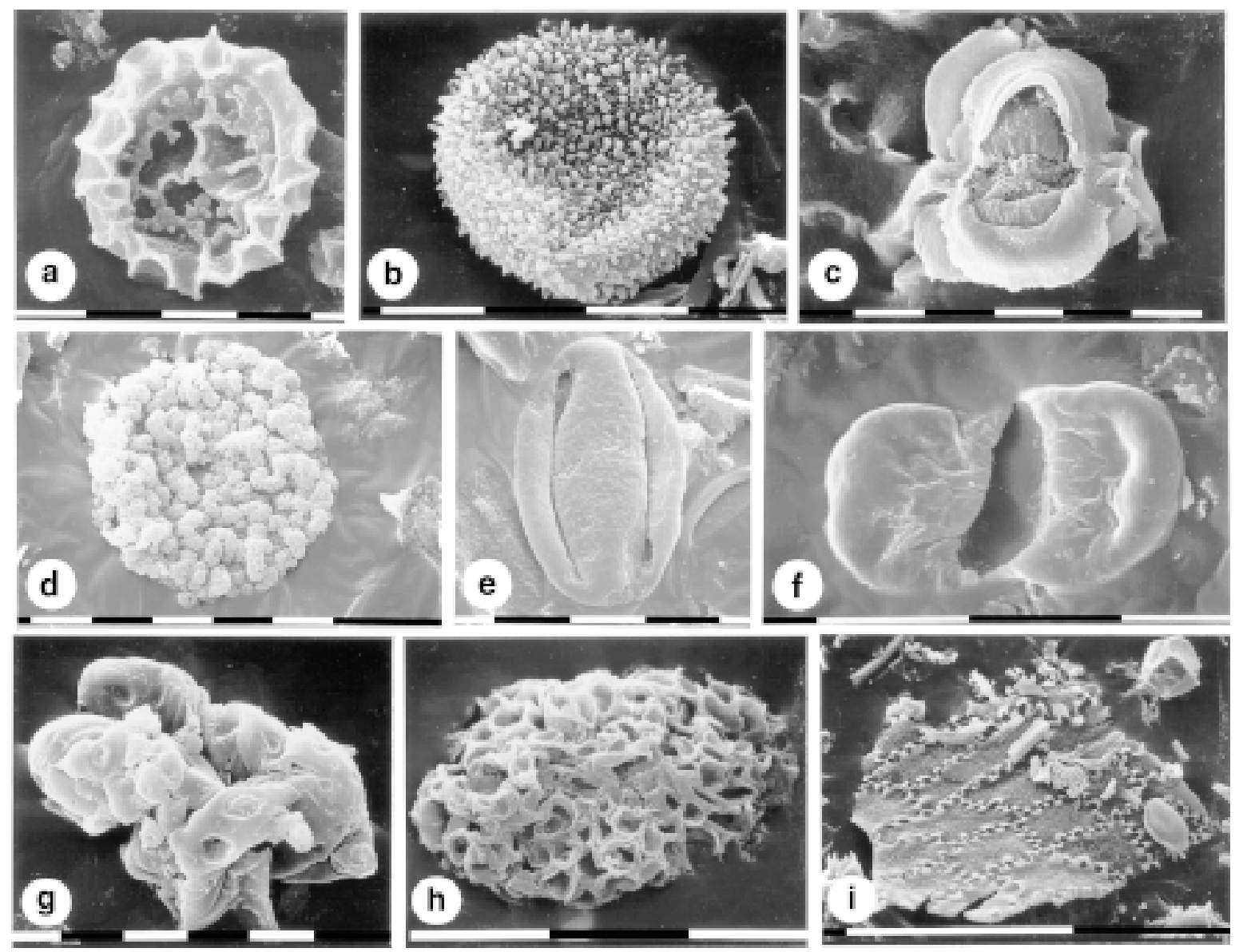

Fig. 3. Scanning electron micrographs of selected palynomorphs from Killeröd. The bar line represent 10 microns in all micrographs except (i) where it represents $0.1 \mathrm{~mm}$. a) Lycopodiumsporites austroclavatidites (Cookson) Potonié, (sample $40.7 \mathrm{~m}$ ). b) Osmundacidites wellmanii Couper, (sample $40.7 \mathrm{~m}$ ). c) Rhaetipollis germanicus Schulz, (sample $40.7 \mathrm{~m}$ ). d) Cerebropollenites mesozoicus Couper, (sample $40.7 \mathrm{~m}$ ). e) Eucommiidites troedssoni Erdtman, (40.7 m). f) Vitreisporites pallidus (Reissinger) Nilsson, (sample $40.7 \mathrm{~m}$ ). g) (sample $40.7 \mathrm{~m}$ ) \& h) (sample $40.3 \mathrm{~m}$ ) Botryococcus colonies at different stages of development. i) Microscopic remains of mega plant fossils, (sample $40.7 \mathrm{~m}$ ).

nomorphs. Further two index species were found, namely Rhaetipollis germanicus Schulz (Fig. 3c), Vitreisporites bjuvensis Nilsson and the accessory species Aratisporites minimus Schulz, Calamospora tener (Leschik) Mädler and Densoisporites velatus Weyland \& Krieger. Other selected species found in sample 40.7 $\mathrm{m}$ are illustrated in Figure 3 and include Lycopodiumsporites austroclavatidites (Cookson) Potonié, Osmundacidites wellmanii Couper, Cerebopollenites mesozoicus Couper, Eucommiidites troedsoni Erdtman, Vitreisporites pallidus (Reissinger) Nilsson and Botryococcus. The palynofacies of this sample differs from the previous by containing a greater number of other well preserved microscopic plant remains which include cuticles and spore tetrads.

\section{Discussion}

On petrographical and sedimentological grounds it seems most likely that the pre-Quaternary section at Killeröd belongs to the Upper Triassic Kågeröd Formation followed by strata belonging to the RhaetianHettangian Höganäs Formation (Fig. 4). This is based on the comparison with well documented Upper Triassic strata in NW Skåne, e.g. from outcrops at Bälteberga, Norra Albert, Lunnom and Vallåkra (Sivhed \& Wikman 1986; Norling et al. 1993), from borehole investigations such as Valhall-1 (Guy-Ohlson 1981), Görslöv and Klappe-1 (Norling \& Wikman 1990) and drillcores in SW Skåne such as Svedala-1 and Höllviksnäs-1 (unpublished data).

From the palynological point of view the greatest similarity to palynomorph assemblages from adjacent 


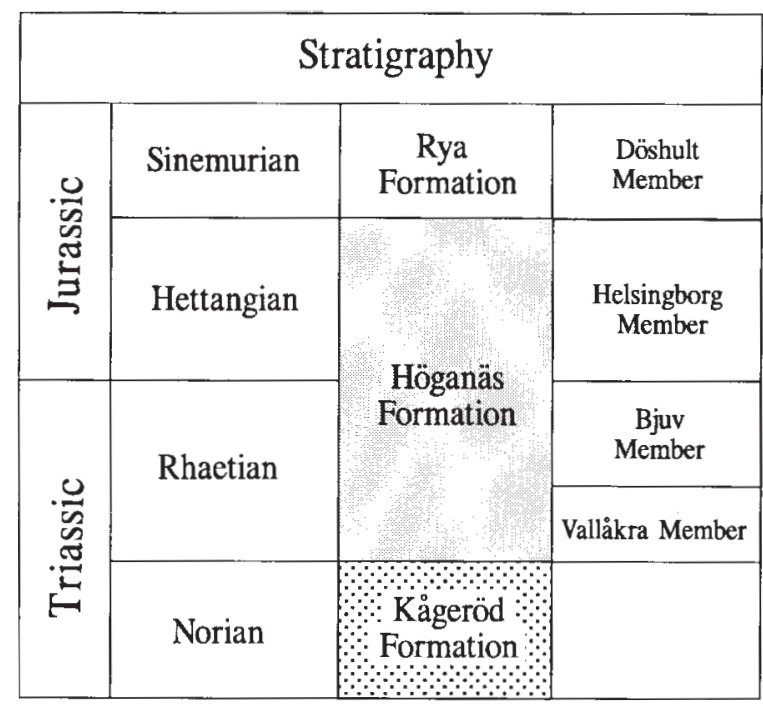

Fig. 4. Lithostratigraphical scheme of the Upper TriassicLower Jurassic strata in NW Skåne.

areas is with Assemblage no 3 of the Gassum-1 Well of the Danish Sub-basin, Jutland (Nielsen 1988). Thus the Killeröd samples at 40.3 and $40.7 \mathrm{~m}$ are dated as being of Rhaetian age and correlated, on the basis of their palynomorph content, with the Rhaetian part of the Gassum Formation. From comparison of species assemblage, preservation and frequencies of fossils, it is believed that the above investigated samples are older than those described from Valhall borehole in the Ängelholm Trough (Guy-Ohlson 1981). The determination of a Rhaetian age for the palynoflora provides the first concrete evidence for the existence of such sediments in this area. This in turn extends the northern limit of known occurrences of Rhaetian sediments in Sweden.

Sedimentological features in the cores at Killeröd including rootlet horizons, coal layers, cross-bedding and clays, together with the rich palynoflora, indicate deposition in a fluviatile floodplain environment. The presence of older colonies (Fig. 3h) of the aquatic, green microalga Botryococcus is indicative of prolonged freshwater (limnic) influence.

\section{General review of Kågeröd and Höganäs Formations in Skåne}

The Upper Triassic (Norian) of Skåne is represented by the $<300 \mathrm{~m}$ thick Kågeröd Formation displaying an overall fining upward trend (Troedsson 1942; Norling \& Wikman 1990). Within the Sorgenfrei-Tornquist Zone the formation occurs in the western part of Skåne both as bedrock surface and subcropping Rhaetian-Lower Jurassic deposits (Fig. 5). The formation is dominated by immature conglomerates, arcoses and mudstones. The sediments are deficient of organic material and rich in ironoxides such as hematite. The coarse clastics grade basinward into clays and mudstones with nodules of carbonate and halite pseudomorphs (Arndorff 1994). The dominance of poorly sorted coarse clastic intervals with several matrix supported paraconglomerates indicates a landscape with significant relief. The Kågeröd Formation is interpreted as representing alluvial fans building off the flanks of local fault bounded basins and ephemeral rivers rapidly transporting and aggrading material into the basin area. The upper part of the Kågeröd Formation includes an increasing amount of red clays interbedded by thin coarse-grained sandstones indicating a lowering of the hinterland relief. Carbonate rich levels, found in SW Skåne, are interpreted as representing conglomeratic calcretes influenced by vadose waters in an arid to semiarid environment (Arndorff 1994).

During the Rhaetian there was an overall change in the environment into more humid climatic conditions which induced radical changes in the mechanisms of weathering and deposition. Within the grabens, rates of subsidence decreased and there was a general lowering of the whole area towards the Norwegian-Danish Basin. The grabens or local basins were infilled with clastics and progressively overstepped as indicated by the wider distribution of Rhaetian-Hettangian deposits (Fig. 5) which suggests that, by the end of the Triassic, there was a relatively uniform deposition all over Skåne. Rhaetian-Hettangian strata are best represented and most complete in NW Skåne, where they are dominated by sandstones, clays and coals of deltaic, cyclic character (Höganäs Formation) (Ahlberg 1994).

The <250 m thick Höganäs Formation (Troedsson 1951; Sivhed 1984; Sivhed \& Wikman 1986) is represented by alluvial to paralic sandstones, mudstones, coal seams and palaeosols. It occurs both as subcrop and bedrock surface over large parts of SW Skåne (Fig. 5). Palynomorphs suggest a Rhaetian to Hettangian age (Lund 1977; Guy-Ohlson 1981). The formation is subdivided into the Rhaetian Vallåkra and Bjuv Members and the Hettangian Helsingborg Member (Fig. 4). The Vallåkra Member (Sivhed 1984) comprises poorly stratified kaolinitic and smectitic mudstones and sandstones, yielding in its upper parts a restricted marine fauna (Troedsson 1948, 1951). Kaolinitic mudstones, heteroliths, and fine-grained quartz arenites are typical of the Bjuv Member which is interpreted to represent floodplain deposits, including paleosols, underclay and coal, interbedded by fluvial channel and crevasse splay sandstones. The member was primarily formed in fresh water environments. The succeeding Helsingborg Member (Troedsson 1947) similar to the Bjuv Member includes several marine incursions and is interpreted to be of deltaic origin (Ahlberg 1994). The deposition and diagensis 
Fig. 5. Distribution of Norian and RhaetianHettangian strata in Skåne.

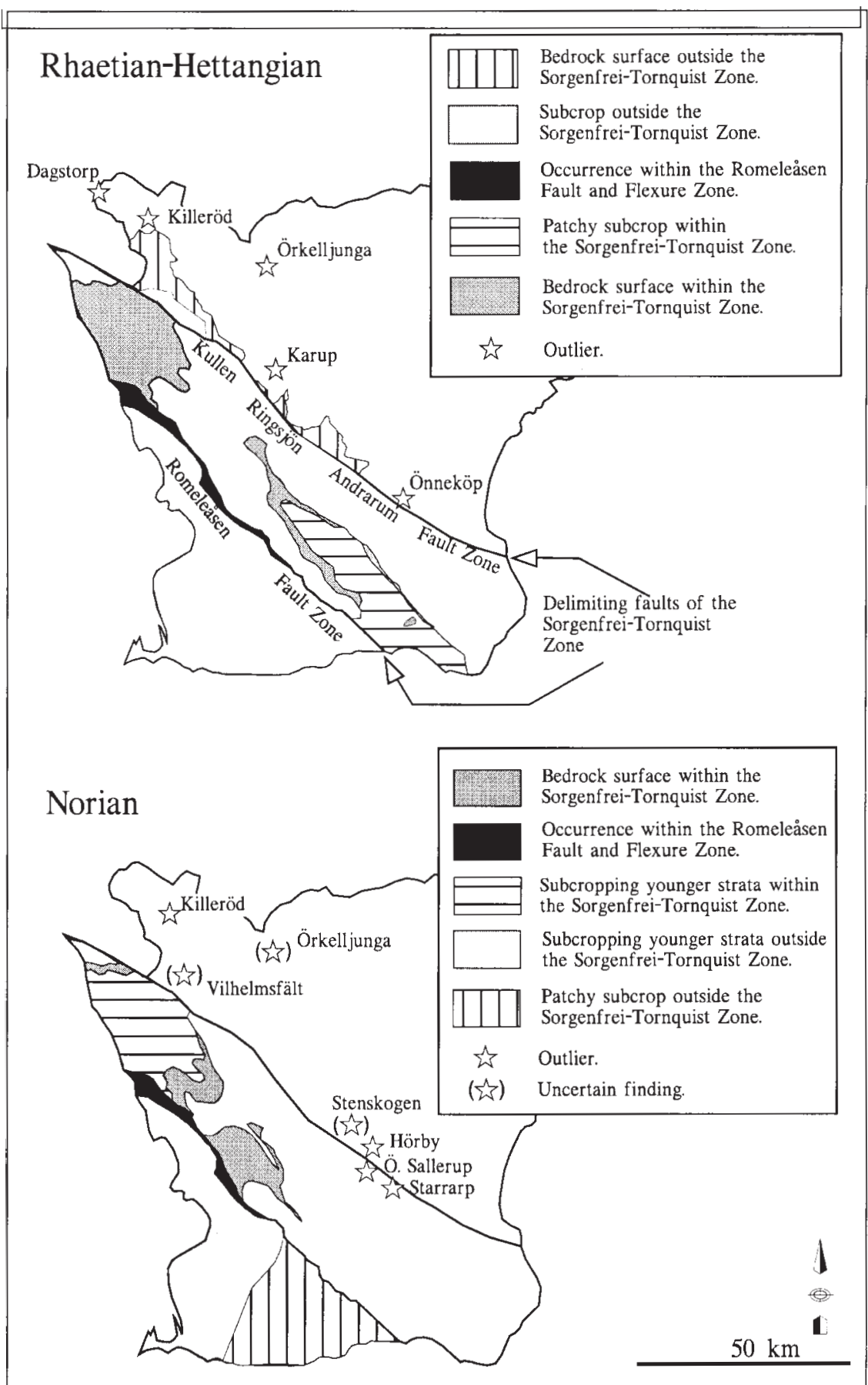


are described in detail by Ahlberg $(1990,1994)$ and Pienkowski (1991).

Beside the Höganäs Formation the $<50 \mathrm{~m}$ thick Höör Sandstone, which outcrops in the central part of Skåne, is also of Rhaetian-Hettangian age, according to analyses of its macro and micro flora (Troedsson 1940; Antevs 1919; Lund 1977). The Höör Sandstone is in detail described by Troedsson (1940), Wikman \& Sivhed (1993) and Ahlberg (1994).

\section{Outlier and position within general framework}

The scattered outliers NE of the Kullen-RingsjönAndrarum Fault Zone were mainly found during water well drillings where cuttings indicate presence of coal, clay and sand of pre-Quaternary origin. Most of these outliers occur in the central and NW parts of Skåne (Wikman \& Sivhed 1993) (Fig. 5). Their stratigraphical affinity is in general uncertain due to poor sample quality. The most reliable findings occur west of Örkelljunga (Wikman \& Sivhed 1992), at Önneköp (Wevferinck 1934) and at Dagstorp (Asklund 1928). The latter location has not been possible to verify by later investigations (Wikman \& Bergström 1987). There are also several observations in boreholes (e.g. at Karup, Fig. 5) and adjacent ditches where middle Jurassic (Tralau 1973) volcanic tuff overlies sandstones and clays of possible Rhaetian-Early Jurassic age (Norling et al. 1993; Wikman \& Sivhed 1993). Up till now there are only a few dubious findings of "Kågeröd-like" deposits north-east of the KullenRingsjön-Andrarum Fault Zone. These findings include reddish clays and coarse clastics in boreholes which might as well be residual heavily weathered crystalline basement rocks, e.g. in the Vilhelmsfält borehole in the Ängelholm Trough (Norling \& Wikman 1990), at Örkelljunga (Wikman \& Sivhed 1992) and at Hörby and Stenskogen (Troedsson 1942).

The preservation of the Killeröd outlier as well as the others north of the Kullen-Ringsjön-Andrarum Fault zone is related to the existence of fault bounded small troughs and gently dipping half grabens. The general composition of the fault bounded structures indicates that they were down faulted during tensional tectonic regimes and it is less likely that they represent compression structures. This implies that the downfaulting occurred during Middle to Late Jurassic times. The Late Cretaceous compression and inversion as well as the Neogene uplift led to a more or less complete removal of pre-existing cover strata, especially north-west of the Kullen-Ringsjön-Andrarum Fault Zone, with the exception of the downfaulted protected successions. Similar so far undiscovered outliers, however, may very well be present at several other locations in the north-eastern parts of Skåne, especially on the Hallandsås and Linderödsåsen Horsts.

\section{Conclusions}

- On petrographical and sedimentological grounds it is most likely that the pre-Quaternary section at Killeröd belongs to the Upper Triassic Kågeröd Formation overlain by strata belonging to the Rhaetian-Hettangian Höganäs Formation.

- Based on the palynomorph assemblage a Rhaetian age is verified for the uppermost part of the succession.

- In the section corresponding to the Höganäs Formation sedimentological features including rootlet horizons, coal layers cross-bedding and clays, together with the rich palynoflora, indicate deposition in a floodplain environment with significant freshwater influence.

- The outlier at Killeröd is the first verified finding of strata belonging to the Kågeröd Formation northeast of the Kullen-Ringsjön-Andrarum Fault Zone.

- The preservation of the Killeröd outlier as well as other outliers is related to the existence of fault bounded small troughs and gently dipping half grabens down-faulted during Middle to Late Jurassic tensional tectonic phases.

\section{Acknowledgements}

Sincere thanks are expressed to Yvonne Arremo and Lars Imby for their much appreciated help.

\section{Dansk sammendrag}

Nær Killeröd, på sydsiden af Hallandsås-horsten, findes en $15 \mathrm{~m}$ tyk sedimentær lagserie, som omfatter grålige og hvide sandsten, ler med højt organisk indhold og kullag, samt rødt, sandet ler og muddersten. Denne lagserie overlejrer det dybt forvitrede grundfjeld. Lagseriens $\emptyset v r e$ del foreslås henført til Höganäs Formationen og antages at være fra Rhætien. De underliggende røde, finkornede sedimenter tolkes, på basis af deres litologi, som tilhørende Kågeröd Formationen fra Norien. Höganäs Formationen omfatter krydslejrede sandsten, rodhorisonter, kullag og ler, som sammen med den rige palyno-flora tyder på, at aflejringsmiljøet har været en flodslette.

Sedimenterne ved Killeröd samt andre isolerede sedimentforekomster inden for det område, som er påvirket af den sent kretassiske inversion og neogene hævning, er bevaret i små forkastningsbassiner. Disse er knyttet til en mellem til sen jurassisk tensional tektonisk fase. De sedimentære karakteristika i Rhætien aflejringerne ved Killeröd støtter den antagelse, at de $\varnothing v$ re triassiske aflejringer oprindeligt har har haft en langt større udbredelse end nu. Derudover er sedimenterne ved Killeröd den første påvisning af Kågeröd Formationen i området nordøst for Kullen-RingsjönAndrarum forkastningszonen. 


\section{References}

Ahlberg, A. 1990: Provenance, stratigraphy, palaeoenvironments and diagenesis of the Lower Jurassic strata in the Helsingborg railway tunnel, southern Sweden. Lund University Licentiate Thesis 2, 54 pp. Lund

Ahlberg, A. 1994: Deposition and diagenesis of the Rhaetian-Hettangian in Skåne, southern Sweden. University of Lund, Lund Publications in Geology 123, 16 pp.

Antevs, E. 1919: Die Liassische Flora des Höörsandsteins. Kungliga Vetenskapsakademins Handlingar 59, 71 pp.

Arndorff, L. 1994: Upper Triassic and Lower Jurassic palaeosols from southern Scandinavia. University of Lund, Lund Publications in Geology 116, 30 pp.

Asklund, B. 1928: Strandflaten på Sveriges Västkust. GFF 50, 801-810.

Bergström, J. 1985: Zur tektonischen Entwicklung Schonens (Südschweden). Zeitschrift für angewandte Geologie 31, 277-280.

Boldreel, L. \& Japsen, P. (eds), 1998: Neogene Uplift and Tectonics areound the North Atlantic. International workshop. Geological Survey of Denmark and Greenland, 121 pp. Copenhagen.

Dahlin, T. 1996: Motståndet avslöjar tillståndet. Geologiskt Forum 12, 8-11.

Erlström, M., Thomas, S. A., Deeks, N. \& Sivhed, U. 1997: Structure and tectonic evolution of the Tornquist Zone and adjacent sedimentary basins in Skåne and the southern Baltic Sea area. Tectonophysics 271, 191-215.

Guy-Ohlson, D. 1981: Rhaeto-Liassic palynostratigraphy of the Valhall Bore no. 1, Skåne. GFF 103, 233-248.

Jubitz, K.-B., Znosko, J. \& Franke, D. (eds). 1988: Lithologic-palaeogeographic map of the Pliensbachian. International Geological Correlation Programme (IGCP), Project No. 86. Scale 1:1 500 000. Two sheets with inset maps (1:10 000 000) of all Lower Jurassic Stages plus the Bajocian and Bathonian. International coordinator: R. Dadlez, Poland. Swedish coordinators: E. Norling \& U. Sivhed. Berlin.

Lund, J. J. 1977: Rhaetic to Lower Liassic palynology of the onshore south-eastern North Sea Basin. Danmarks Geologiske Unders øgelse 109, 1-109.

Michelsen, O. 1997: Mesozoic and Cenozoic stratigraphy and structural development of the Sorgenfrei-Tornquist Zone. Z. dt. geol. Ges. 148, 33-50.

Nielsen, M. V. 1988: Palynological investigation of the Upper Triassic deposits in the well Gassum No. 1 from the Danish Sub-basin (Jutland, Denmark). Pre-Quaternary Compendium 10.88:1-35. Paly-Dat.

Norling, E. \& Bergström, J. 1987: Mesozoic and Cenozoic tectonic evolution of Scania, southern Sweden. Tectonophysics $137,7-19$.

Norling, E. \& Wikman, H. 1990: Description to the map of solid rocks Höganäs NO/Helsingborg NV. Sveriges Geologiska Undersökning Af 129, 123 pp.

Norling, E., Ahlberg, A., Erlström, M. \& Sivhed, U. 1993: Guide to the Upper Triassic and Jurassic geology of Sweden. Sveriges Geologiska Undersökning Ca 82, 71 pp.

Pienkovski, G. 1991: Liassic sedimentation in Skåne, southern Sweden. Hettangian-Sinemurian of the Helsingborg area. Facies 24, 39-86.

Sivhed, U. 1984: Litho- and biostratigraphy of the Upper Triassic-Middle Jurassic in Skåne, southern Sweden. Sveriges Geologiska Undersökning C 806, 31 pp.
Sivhed, U. \& Erlström, M. 1998a: Bedrock map 1C Trelleborg NV, scale 1:50 000. Sveriges Geologiska Undersökning Af 196.

Sivhed, U. \& Erlström, M. 1998b: Bedrock map 1C Trelleborg NO, scale 1:50 000. Sveriges Geologiska Undersökning Af 198.

Sivhed, U. \& Erlström, M. 1998c: Bedrock map 1C Malmö SV, scale 1:50 000. Sveriges Geologiska Undersökning Af 193.

Sivhed, U. \& Erlström, M. 1998d: Bedrock map 1C Malmö SO, scale 1:50 000. Sveriges Geologiska Undersökning Af 194.

Sivhed, U. and Wikman, H. 1986: Beskrivning till berggrundskartan Helsingborg SV. Sveriges Geologiska Undersökning Af 149, 108 pp.

Tralau, H. 1973: En palynologisk åldersbestämning av vulkanisk aktivitet i Skăne. Fauna och Flora 68, 121-125.

Troedsson, G. 1940: Om Höörs sandsten. GFF 62, 245-283.

Troedsson, G. 1942: Bidrag till kännedomen om kågerödsformationen i Skåne. GFF 64, 289-328.

Troedsson, G. 1947: Berggrunden inom Hälsingborgs stad. GFF 69, 385-432.

Troedsson, G. 1948: Om fynd av rätiska fossil i Skåne. GFF 70, 528-550.

Troedsson, G. 1951: On the Höganäs series of Sweden. Lunds Universitets Årsskrift, 47, 268 pp.

Wevferinck, T. 1934: Om rät-liasförekomsten vid Önneköp. GFF 56, 621-623.

Wikman, H. \& Sivhed, U. 1992: Beskrivning till Berggrundskartan Helsingborg NO. Sveriges Geologiska Undersökning Af 148, 83 pp.

Wikman, H. \& Sivhed, U. 1993: Beskrivning till berggrundskartan Kristianstad SV. Sveriges Geologiska Undersökning Af 155, 106 pp. 